\title{
DÜBLIN
}

Technological University Dublin

ARROW@TU Dublin

\section{Development of a Cloud Solution for SMEs in the Irish Construction Industry}

\author{
Alan V. Hore \\ Technological University Dublin, alan.hore@tudublin.ie \\ Alan Redmond \\ Technological University of Dublin, d99101075@mydit.ie \\ Roger West \\ Trinity College, rwest@tcd.ie
}

Follow this and additional works at: https://arrow.tudublin.ie/beschreccon

Part of the Construction Engineering and Management Commons

\section{Recommended Citation}

Redmond, A, Hore, A., West R., (2010), Development of a Cloud Solution for SMEs in the Irish Construction Industry, 8th European Conference on Product \& Process Modelling, University College Cork, September 14, 2010 doi:10.21427/mtm9-m265

This Conference Paper is brought to you for free and open access by the School of Surveying and Construction Management at ARROW@TU Dublin. It has been accepted for inclusion in Conference papers by an authorized administrator of ARROW@TU Dublin. For more information, please contact arrow.admin@tudublin.ie, aisling.coyne@tudublin.ie,gerard.connolly@tudublin.ie.

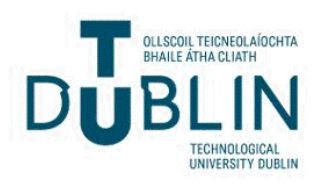




\title{
Development of a Cloud Solution for SMEs in the Irish Construction Industry
}

\author{
A.V. Hore \& A. Redmond \\ School of Real Estate and Construction Economics, Dublin Institute of Technology, Bolton Street Dublin 1, \\ Ireland. \\ R.P. West \\ Department of Civil, Structural and Environmental Engineering, Trinity College, Dublin 2, Ireland.
}

\begin{abstract}
There is a strong emerging trend within the Information Communication Technology (ICT) sector for replacing traditional packaged desktop applications with Web based, outsourced products and services. The drive for this innovative solution is its contribution to enabling software to be developed, delivered and consumed in discrete chunks (known as services) liberating the users from traditional computing and providing services accessible across a range of devices and appliances. The objective of this paper is to report on the progress towards defining this Web based service, commonly known as 'Cloud computing', for Small to Medium Size Enterprises (SMEs) in the Irish construction industry. The authors will present the results of a Construction IT Alliance (CITA) Enterprise Innovation Network (EIN) marketplace survey that combined vendor and consumer attitudes. This paper will also act as recommendation for the future development of a re-engineered software solution that will utilise the benefits of Web services in the Irish construction industry.
\end{abstract}

\section{INTRODUCTION}

The use of ICT has proven instrumental in creating productivity gains within global markets, for example, through reduced transaction costs, scalability, and fast, reliable information flows and enhanced online collaboration tools and new ways to market goods and services (Pepper et al. 2009). The success and effectiveness of ICT in today's world economies have clearly shaped and improved the supply chain management process, communication ability and business, and still new innovative solutions are being adapted (Hore et al. 2009).

Hore et al, (2010) investigates the work of CITA in Ireland in encouraging SMEs interest in subscribing to a software marketplace that deploys an open source solution. The paper publishes the results of an EIN programme survey. The survey was based on a sample of 27 enterprises comprising of both customers and vendors. The overall results demonstrated the need for Cloud computing or something similar that would improve the competitive positions of SMEs in Ireland by allowing them to have access to software that was previously only the domain of large enterprises.

This paper is a continuation of the research involved with the EIN programme. It will present the survey results of almost 90 enterprises in the construction industry. Graphical analyses will be presented as part of illustrating the drivers, barriers, and benefits associated with Cloud computing and what this innovative concept means to the Irish construction SME sector.

\section{THE SURVEY}

The survey comprised of two samples customers and vendors in the construction industry. The structures of both questionnaires were designed to be similar, in order, to evaluate whether there is a strong relationship between the two samples. The methodology used for both questionnaires were designed on quantitative and qualitative research, which can be classified under two categories. Firstly exploratory research was used to diagnose a situation, screening alternatives and to discover new ideas. Secondly, attitudinal research used to subjectively evaluate the opinion, view or the perception of a person, towards a particular object. The principal difference between the vendor's and customer's surveys was the rephrasing of the questions in respect to one party engaging in providing applications and the other consuming one.

The survey was divided into four sections similar to a format previously tested by Hore and West (2005) with certain aspects of content referring to Naoum (2007). Each of the four segments was designed to analyse the potential of creating a business case study for Cloud applications in the Irish construction industry. 
Use of ICT Up-take: identifying the overall business strategy of the respondents and their attitudes towards purchasing software and their use of ICT in the next three years. The purpose behind investigating this strategy was to establish the market requirement for SMEs.

Driving forces: the main attributes associated with attracting construction enterprises to use Cloud computing. The ten most standard types of drivers associated with using Cloud were presented in a ten point ranking scale format in the questionnaires.

Perceived Barriers to adoption: the industry's most common perceived barriers for rejecting the adoption of a centralized heterogeneous network based on OS principles. The ten listed barriers used in the questionnaires were based on secondary data collected from various national and international publications on this topic.

Benefits of Cloud computing: questions relating to opinions targeting the perceived benefits of Cloud computing. This question was presented as a likert scale to measure a range of options from "Strongly agree" to "Strongly disagree" in both questionnaires. The results of the perceived benefits could only assist in judging whether this service would be a success for SMEs in the Irish construction industry.

\section{ICT UP-TAKE}

The purpose of this section of the survey was to investigate a firm's management's strategy towards software and how the market views potential gains from future applications. The format of the questions in this section was based on the positivism approach of reasoning (the study of reality and beyond). This type of research relates to quantitative data analysis (factual questions). However, the majority of the questions were followed by an open-ended question which requires an interpretivism approach to qualitative data analysis (data expressed in words) (Peltomaki \& Nummela's, 2004).

\subsection{ICT usage in construction in the next 3 years}

In identifying the markets philosophy on capital expenditure $32 \%$ of the combined vendor and consumer totals indicated a great increase in their firm's involvement in eBusiness and the use of ICT in the next three years. $50 \%$ of the respondents showed some increase while only $10 \%$ of almost 90 enterprises predicted no increase. Figure 1 illustrates the portions in graphical terms.

\subsection{SMEs low-uptake of ICT}

The sample singled out SMEs as the main attribute for the low level of ICT up-take in construction, coupled with the fact that the majority of construc- tion firms in Europe are SMEs (97\%, see e-Business W@tch, 2006). The respondents expressed an overall mixed reaction to this notion. Table 1 summarises the respondent's opinion to the statement, 'that the high concentration of SMEs in the construction industry is generally identified as the reason for the low ICT Uptake'. The most compelling result from this question is that the SMEs themselves view this as the reason (46\%) in comparison to ICT vendors $(26 \%)$.

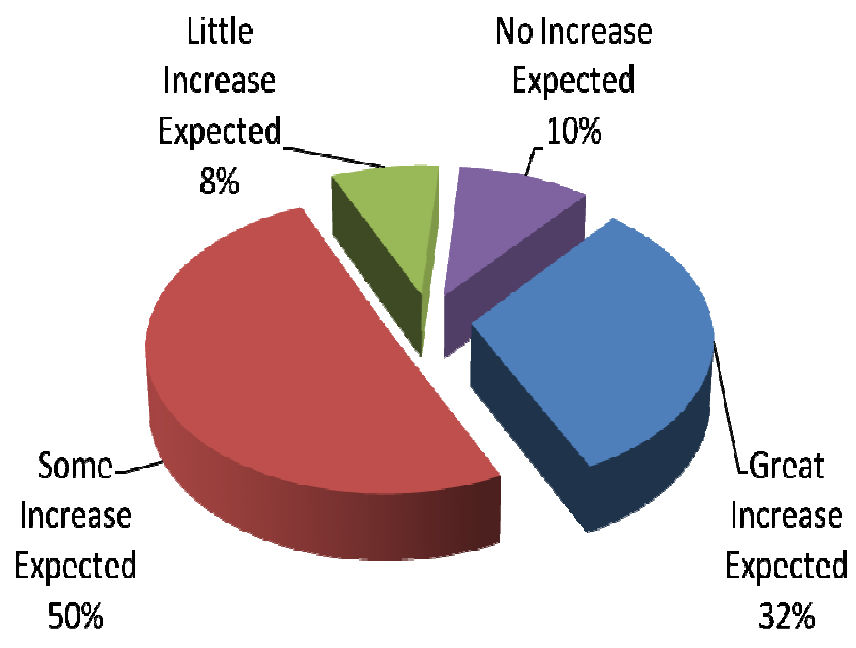

Figure 1. eBusiness and the use of ICT from the survey.

Table 1. SMEs the reason for low ICT up-take

\begin{tabular}{llll}
\hline Opinion & Customer & Vendor & Overall \\
\hline Strongly Agree & $13 \%$ & $13 \%$ & $13 \%$ \\
\hline Agree & $43 \%$ & $26 \%$ & $35 \%$ \\
\hline No Opinion & $26 \%$ & $39 \%$ & $33 \%$ \\
\hline Disagree & $18 \%$ & $19 \%$ & $18 \%$ \\
\hline Strongly Disagree & $0 \%$ & $3 \%$ & $1 \%$ \\
\hline
\end{tabular}

One of the customers expressed that because they are constantly occupied they have a problem with identifying what applications are available and how these can benefit their business. They do not know where to start, with so much information online. A further question requested the respondents to express the reason for their answer. Figure 2 illustrates the tabulation of the responses in graphical form. $60 \%$ 
of the $40 \%$ of the respondents that disagreed with this statement were vendors.

\section{- Customer $\quad$ Vendor}

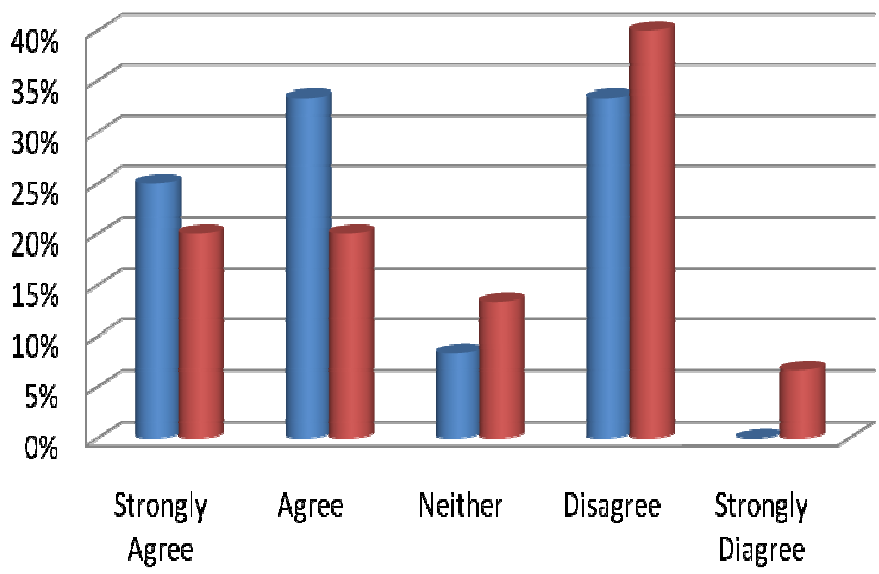

Figure 2. Qualitative analysis of SMEs as to the reason for low ICT up-take

In order to identify if vendors were developing products for the SMEs construction market the survey requested the vendors to state if they had identified construction SMEs, as a particular niche section for their software products. The initial response indicated a $71 \%$ positive assurance to the construction SME sector. However, after further analysis of the descriptive responses the figure increased to $87 \%$. The interpretivism increase of $16 \%$ related to converting negative responses that actually indicated in their reasoning that any market using their product is a potential market. Other negative responses suggested that their services are marketed across a whole range of firms.

\section{DRIVING FORCES FOR CLOUD COMPUTING}

Both questionnaires requested each sample to rank in order $1-10$ (10 being the highest) the factors that will attract or likely attract their organization to providing Cloud services. A summary of the overall results is shown in Table 2.

In combining both vendors and customers opinions Table 2 can act as an indication of how the construction industry perceives the valuable aspects of cloud computing. The driver associated with a green solution surprisingly ranked the lowest in comparison to the highest driver value, 'added service'. The unprecedented decline in Irish construction may be a strong contributor as to why improving business needs is ranked high in contrast to sustainability needs. In separately analysing the two samples the ranking of the vendors and customers can be examined in further detail. Table 3 identifies the results of both samples.

Table 2. Drivers for Cloud computing

\begin{tabular}{cl}
\hline Ranking & Drivers \\
\hline $\mathbf{1 0}$ & $\begin{array}{l}\text { Value added service - Improves the businesses } \\
\text { product standard. }\end{array}$ \\
$\mathbf{9}$ & $\begin{array}{l}\text { Sales - Increases market share. } \\
\text { Total cost - Total cost of ownership is predicta- } \\
\text { ble, visible, flexible and lower. }\end{array}$ \\
$\mathbf{7}$ & $\begin{array}{l}\text { IT Costs - Eliminate IT costs and concerns as- } \\
\text { sociated with maintaining and upgrading sepa- } \\
\text { rate applications. }\end{array}$ \\
$\mathbf{6}$ & $\begin{array}{l}\text { Payment flexibility - Pay per user per month } \\
\text { (user numbers can change per month). }\end{array}$ \\
$\mathbf{5}$ & $\begin{array}{l}\text { Choice - select ICT solutions that are quick to } \\
\text { deploy, easy to use, and will support your busi- } \\
\text { ness processes. }\end{array}$ \\
$\mathbf{4}$ & $\begin{array}{l}\text { Closer collaboration - more frequent communi- } \\
\text { cation and improve relationships along the } \\
\text { supply chain and partner's networks. }\end{array}$ \\
\hline $\mathbf{3}$ & $\begin{array}{l}\text { Access - 24 x } 7 \text { access from any online PC an- } \\
\text { ywhere in the world. } \\
\text { Contract - No commitment (contract is month } \\
\text { by month). }\end{array}$ \\
$\mathbf{2}$ & $\begin{array}{l}\text { Greener solution - particularly for organisa- } \\
\text { tions that traditionally have operated their own } \\
\text { data centres in regions with high electricity } \\
\text { costs. }\end{array}$ \\
\hline
\end{tabular}

The separate rankings of the samples in Table 3 summarises the correlation between the two results. The averages of all the values from the respondents of both samples were used to determine the overall ranking. Tables 3 show that both payment flexibility and closer collaboration were ranked significantly differently by customers and vendors. The most concerning point to note is that customers have either not experienced the use of collaboration tools in the Irish construction industry or having availed of them, found their purpose to be surplus to their need.

Table 3. Individual sample driver rankings

\begin{tabular}{lcc}
\hline Ranking & Customer & Vendor \\
\hline Greener solution & 1 & 1 \\
\hline Payment flexibility & 4 & 8 \\
\hline Closer collaboration & 3 & 7 \\
\hline Sales & 10 & 9 \\
\hline Value added service & 9 & 10 \\
\hline Contract & 2 & 3 \\
\hline Total cost & 8 & 5 \\
\hline Access & 3 & 2 \\
\hline IT Costs & 7 & 4 \\
Choice & 6 & 6 \\
\hline
\end{tabular}

Figure 3 illustrates the data collected in Table 3. 
The correlation scatter diagram is used to assess whether there appears to be a correlation between two measurements (Naoum, 2007). It is evident from Table 3 and Figure 3 that there is some divergence of opinion between the customers and vendors ranking opinions in relation to the question. The linear regression line in Figure 3 illustrates the trendline relationship between the sample results. As indicated from the diagram, greener solutions and choice are two points on the line with sales and value added service being closely correlated with both samples. To conclude the correlation graph identifies that a few of the driving forces were ranked sufficiently close to the trendline to identify that there was a broad agreement between ranking.

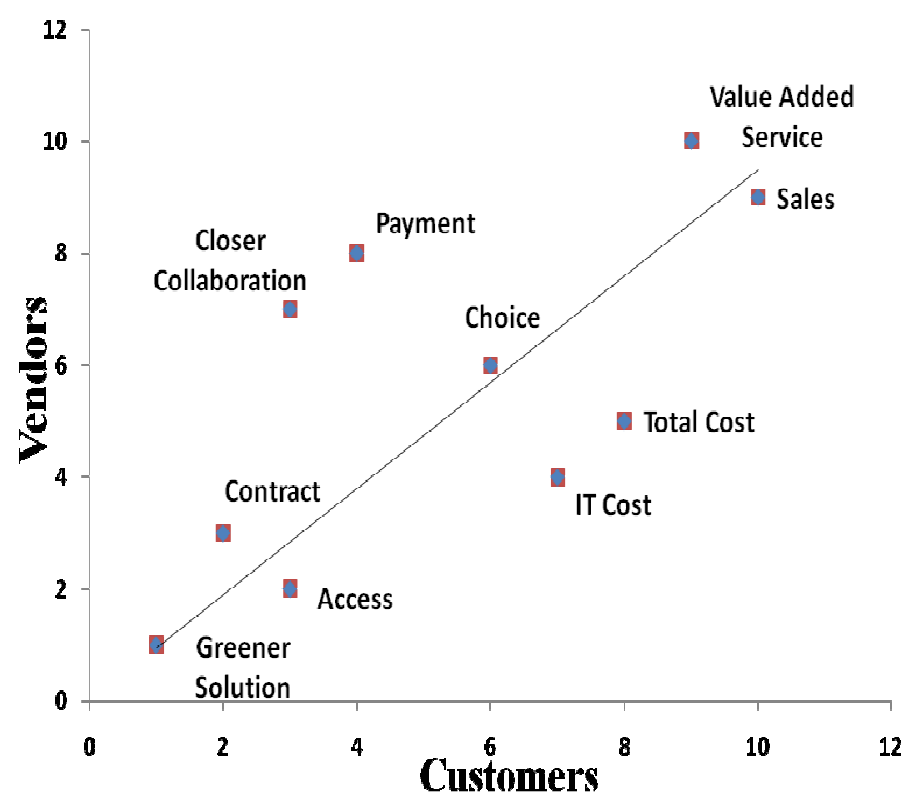

Figure 3. Correlation drivers of Cloud computing.

\section{BARRIERS TO CLOUD COMPUTING}

The barriers for adoption question was formatted identically to the drivers question with both samples being requested to rank in order $1-10$ (10 being the highest). The attitudinal barrier statements provided were collected from various perceptions of Cloud computing in the media and literature reports. Figure 4 illustrates the correlation between the two samples.

From review of Table 4, 'lack of awareness or knowledge' is ranked the overall highest. From this a comparison can be made with section 3.2 of this paper, the analysis relating to ICT up-take by SMEs. One respondent felt that there was too much information online in an unstructured format. This barrier is clearly evident in Table 4 overall rankings. The next major barrier was 'security'. Armburst et al. listed this as number 3 in their top ten obstacles and opportunities for Cloud computing (Armburst et al. 2009). The lowest ranked barrier was surprisingly 'contract'. In relation to the customers they ranked this the lowest and 'pricing models' ranked as third lowest.

Table 4. Barriers for adoption of Cloud computing

\begin{tabular}{|c|c|c|c|}
\hline Barriers & Customers & Vendors & $\begin{array}{l}\text { Overall } \\
\text { Ranking }\end{array}$ \\
\hline $\begin{array}{l}\text { Knowledge - } \\
\text { Lack of aware- } \\
\text { ness or know- } \\
\text { ledge: }\end{array}$ & 9 & 10 & 10 \\
\hline $\begin{array}{l}\text { Security - Security } \\
\text { concerns: }\end{array}$ & 10 & 8 & 9 \\
\hline $\begin{array}{l}\text { Cost - Total cost of } \\
\text { ownership concerns: }\end{array}$ & 8 & 6 & 8 \\
\hline $\begin{array}{l}\text { Capabilities - Custom- } \\
\text { ers may not possess } \\
\text { adequate eBusiness ca- } \\
\text { pabilities: }\end{array}$ & 3 & 9 & 7 \\
\hline $\begin{array}{l}\text { Choice - "We can't } \\
\text { find the specific appli- } \\
\text { cation we need": }\end{array}$ & 7 & 5 & 6 \\
\hline $\begin{array}{l}\text { Integration - Lack of } \\
\text { integration and intero- } \\
\text { perability of software: }\end{array}$ & 4 & 7 & 5 \\
\hline $\begin{array}{l}\text { Customisation - Lack } \\
\text { of customisation: }\end{array}$ & 5 & 4 & 4 \\
\hline $\begin{array}{l}\text { Pricing - Complicated } \\
\text { pricing models: }\end{array}$ & 6 & 1 & 3 \\
\hline $\begin{array}{l}\text { Performance - Applica- } \\
\text { tion performance: }\end{array}$ & 2 & 3 & 2 \\
\hline $\begin{array}{l}\text { Contract - "We're } \\
\text { locked in with our cur- } \\
\text { rent vendor": }\end{array}$ & 1 & 2 & 1 \\
\hline
\end{tabular}

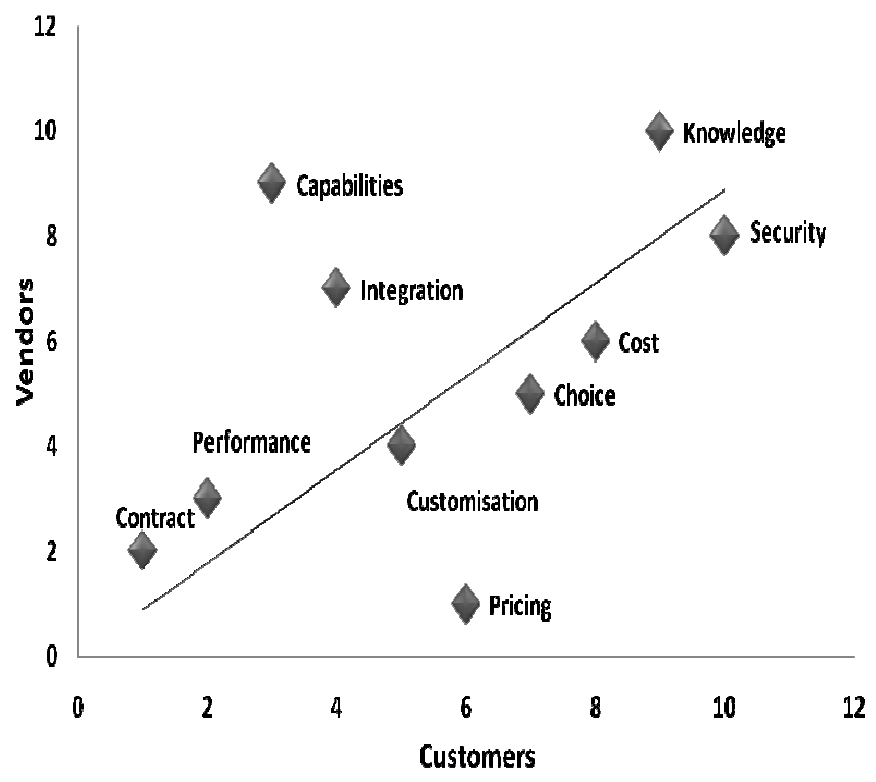

Figure 4. Correlation barriers on adoption of Cloud computing.

The correlation diagram Figure 4 illustrates that there is some evidence of divergence of opinion be- 
tween customers and vendors. benefits of cloud computing

The eight perceived benefits of Cloud computing were asked in both questionnaires. The actual statements relate to Ramanujam's (2007) key points as to why Cloud/On-Demand would be a smart choice for companies. Table 5 demonstrates the opinions of both samples (customers and vendors) in relation to Ramanujam's perceived benefits:

Table 5. Perceived benefits of Cloud computing.

\begin{tabular}{llllll}
\hline $\begin{array}{l}\text { Perceived } \\
\text { Benefits of } \\
\text { Cloud }\end{array}$ & $\begin{array}{l}\text { Strongly } \\
\text { agree }\end{array}$ & Agree & $\begin{array}{l}\text { No } \\
\text { Opinion }\end{array}$ & Disagree & $\begin{array}{l}\text { Strongly } \\
\text { disagree }\end{array}$ \\
\hline $\begin{array}{l}\text { Non- } \\
\text { premise }\end{array}$ & $30 \%$ & $40 \%$ & $25 \%$ & $5 \%$ & $0 \%$ \\
$\begin{array}{l}\text { Pay as you } \\
\text { go }\end{array}$ & $45 \%$ & $40 \%$ & $8 \%$ & $7 \%$ & $0 \%$ \\
$\begin{array}{l}\text { Easy role } \\
\text { out }\end{array}$ & $33 \%$ & $43 \%$ & $21 \%$ & $3 \%$ & $0 \%$ \\
$\begin{array}{l}\text { Spread out } \\
\text { cost }\end{array}$ & $43 \%$ & $32 \%$ & $18 \%$ & $7 \%$ & $0 \%$ \\
$\begin{array}{l}\text { Frequent } \\
\text { updates }\end{array}$ & $34 \%$ & $48 \%$ & $18 \%$ & $0 \%$ & $0 \%$ \\
$\begin{array}{l}\text { Focus on } \\
\text { growth }\end{array}$ & $31 \%$ & $41 \%$ & $23 \%$ & $5 \%$ & $0 \%$ \\
$\begin{array}{l}\text { Maintenance } \\
\text { free }\end{array}$ & $42 \%$ & $27 \%$ & $25 \%$ & $5 \%$ & $1 \%$ \\
\hline
\end{tabular}

The results of the frequency distribution in Table 5 are graphically illustrated in Figure 5.

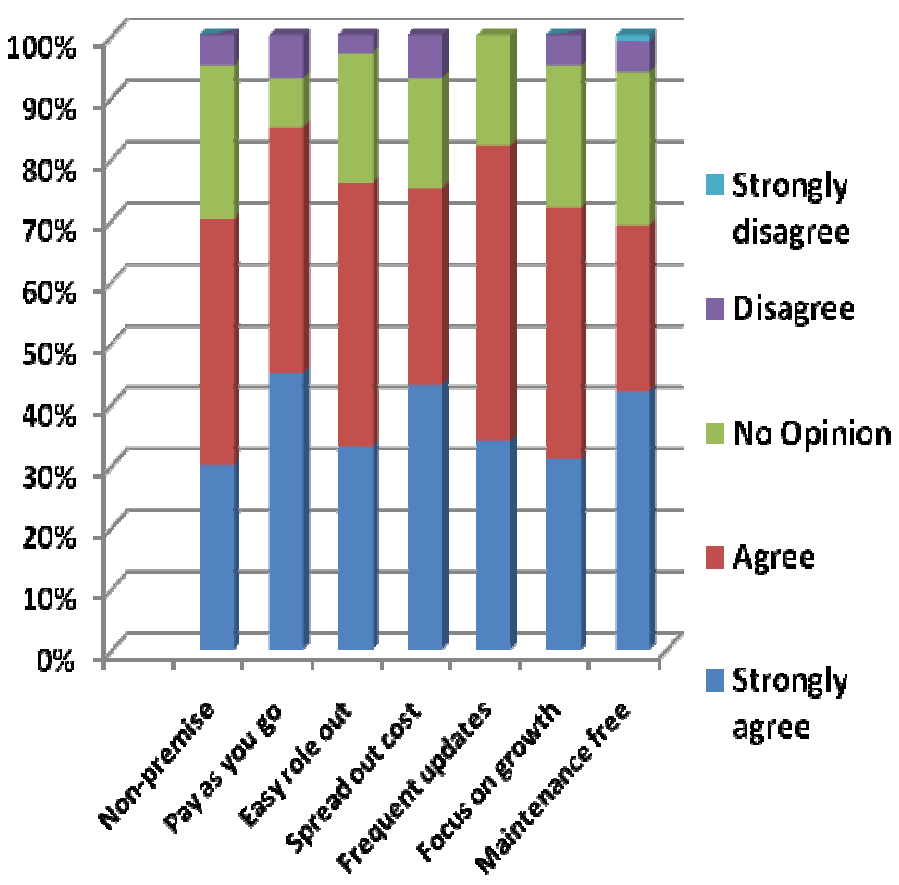

Figure 5. Perceived benefits of Cloud computing.

The combined responses to this question indicate that the majority of the respondents in the construc- tion industry are in favour of the Cloud benefits. The percentages allocated towards disagree and strongly disagree are under $10 \%$. The graph illustrates this by contributing the two largest proportions of colours to strongly agreeing and agreeing (blue and green). Hore et al. analysed the results of this same question in their EIN survey which targeted customer members. The results of that survey showed that $67 \%$ of the customers were undecided as to the concept of having a service managed online. In relation to such benefits, as reducing capital cost of purchasing software and not having to worry about disaster recovery, $25 \%$ of the respondents indicated causation in relation to these benefit (Hore et al. 2010). Table 6 indicates the scores associated with this surveys customer respondents.

Table 6. Customers perceived benefits of Cloud computing.

\begin{tabular}{llllll}
\hline $\begin{array}{l}\text { Perceived } \\
\text { Benefits of } \\
\text { Cloud }\end{array}$ & $\begin{array}{l}\text { Strongly } \\
\text { agree }\end{array}$ & Agree & $\begin{array}{l}\text { No } \\
\text { Opinion }\end{array}$ & Disagree & $\begin{array}{l}\text { Strongly } \\
\text { disagree }\end{array}$ \\
\hline $\begin{array}{l}\text { Non- } \\
\text { premise }\end{array}$ & $52 \%$ & $38 \%$ & $7 \%$ & $3 \%$ & $0 \%$ \\
$\begin{array}{l}\text { Pay as you } \\
\text { go }\end{array}$ & $64 \%$ & $25 \%$ & $7 \%$ & $4 \%$ & $0 \%$ \\
$\begin{array}{l}\text { Easy role } \\
\text { out }\end{array}$ & $45 \%$ & $38 \%$ & $14 \%$ & $3 \%$ & $0 \%$ \\
$\begin{array}{l}\text { Spread out } \\
\text { cost }\end{array}$ & $48 \%$ & $31 \%$ & $17 \%$ & $3 \%$ & $0 \%$ \\
$\begin{array}{l}\text { Frequent } \\
\text { updates }\end{array}$ & $52 \%$ & $31 \%$ & $17 \%$ & $0 \%$ & $0 \%$ \\
$\begin{array}{l}\text { Focus on } \\
\text { growth }\end{array}$ & $48 \%$ & $34 \%$ & $14 \%$ & $3 \%$ & $0 \%$ \\
$\begin{array}{l}\text { Maintenance } \\
\text { free }\end{array}$ & $52 \%$ & $24 \%$ & $24 \%$ & $0 \%$ & $0 \%$ \\
\hline
\end{tabular}

It is evident from Table 6 that overall the customers in the Irish construction industry are not concerned about having their services managed online. Having the benefit of no facilities (non-premise) would enable one to focus their attention towards the customer instead of worrying about unnecessary ICT problems. In contradiction to the EIN survey, Table 6 shows that the customers are in agreement with both the benefits of spreading out costs (capital cost of purchasing software) and maintenance free (disaster recovery). However, in relation to the results of the combined scores (Table 5) both non-premise and maintenance free values did yield the highest percentage of no opinions. This $25 \%$ should be identified as the percentage of the industry that needs to be educated more on these specific benefits of Cloud computing. To conclude, the construction industry perceives the benefits of Cloud computing to be a positive addition in assisting them to becoming more effective and efficient. 


\section{CONCLUSION}

The purpose of this paper was to illustrate the findings of a CITA EIN 2010 survey that highlighted the drivers, barriers, and benefits associated with Cloud computing in the Irish construction industry. The early results of this survey have strongly indicated a need for such a Web-based model that has the ability to promote collaboration between all construction disciplines. The results indicated that 'sales' and 'value added service' were the main incentives for adoption. In analysing the barriers the majority of the respondents agree that 'lack of awareness or knowledge' may deter them from implementing this service. However, the perceived benefits of having convenient on demand network access to a shared infrastructure, with elasticity and consumption-based pricing, has demonstrated to the Irish construction industry the capabilities of this new layer of internet architecture.

In conclusion the next stages of the development will require a small contingent of the Irish SME market to test a recommended developed service. It is envisioned that through the process of a development plan and in collaboration with EIN's SMEs an identified re-engineered software solution will be established. The applications provided for this solution will be chosen from the CITA's software directory. The need for such an innovative solution is to provide SMEs in the Irish construction industry with applications that can assist their construction methods becoming more efficient and effective in a global economy.

\section{REFERENCES}

Armbrust, M., Fox, A., Griffith, R., Joseph, A.D., Katz, R.H., Konwinski, A., Lee, G., Patterson,D.A, Rabkin, A., Stocia, I. \& Zaharia, M. (2009), Above the Clouds: A Berkeley View of Cloud Computing, Electrical Engineering and Computer Sciences University of California at Berkeley, htt://www.eecs.berkeley.edu/Pubs/TechRpts/2009/EE CS-200928.html

Enterprise \& Industry Directorate General (2006), eBusiness W@tch: ICT and e-Business in the Construction Industry, Sector Report No.7/2006.

Hore, A.V., \& West, R.P., (2005), 'A survey of electronic purchasing practice in Ireland: a perspective for the Irish construction industry', the $2^{\text {nd }}$ International Salford Centre for Research and Innovation (SCRI) Research Symposium and International Built and Human Research Week, Salford University, Manchester, 98108.

Hore, A.V., West, R.P. \& Redmond, A. (2009), Creating a Software Marketplace for the SME Community in the Irish Construction Industry, The Construction and Building Research Conference of the Royal Institution of Chartered Surveyors (COBRA), Cape Town 10-11 September, RICS (2009) publication, London, UK.

Hore, A.V., West, R.P. \& Redmond, A. (2010), Software as a Service and its Application in the Irish Construction Industry, $20106^{\text {th }}$ International Conference on Innovation in Architecture, Engineering and Construction, PennState University, Pennsylvania, USA (awaiting publication).

Hurmerinta-Peltomaki, L. \& Nummela, N. (2004), Handbook of Qualitative Research Methods for International Business, published by Edward Elgar Publishing Limited, Cheltenham, Glos GL50 UA, UK, $162-$ 180.

Naoum, S.G. (2007), Dissertation Research and Writing, For Construction Students, Elsevier ButterworthHeinemann Linacre House, Jordan Hill, Oxford OX2 8DP, 200 Wheeler Road, Burlington, MA 01803.

Pepper, R., Rueda-Sabater E.J., Boeggeman, B.C. \& Garrity, J. (2009), The Global Information Technology Report 2008-2009: Mobility in a Networked World, World Economic Forum, printed and bound in Switzerland by SRO-Kundig, Geneva, 2008-2009, 3751.

Ramanujam, B. (2007), Moving SaaS/On-Demand from Dream to Successful Reality: A Practical Solution to Real-World Problems with Contact Centre adoption SaaS/On-Demand, available from http://www.cypcorp.com/leadership/index. php 